\title{
Long-term outcomes in childhood-onset systemic lupus erythematosus: preliminary results of the CHILL-NL study
}

\author{
Noortje Groot ${ }^{1,2^{*}}$, Sylvia Kamphuis ${ }^{2}$, \\ CHILL - NL study group of rheumatologists immunologists nephrologists and internal medicine \\ From 21st European Pediatric Rheumatology (PReS) Congress \\ Belgrade, Serbia. 17-21 September 2014
}

\section{Introduction}

Childhood-onset systemic lupus erythematosus (cSLE) is a more severe disease when compared to adult-onset SLE, with higher disease activity at onset and during disease course, higher percentage of major organ involvement and more rapid accrual of damage. Long-term outcome studies on cSLE are rare.

\section{Objectives}

This study aims to describe the long-term outcomes of patients with cSLE that have reached adulthood.

\section{Methods}

All Dutch rheumatologists, immunologists, nephrologists, haematologists, neurologists were asked to refer cSLE patients to the CHILL-NL (CHILdhood Lupus in the NetherLands) study team. The study was promoted in magazines and on websites of the Dutch SLE patient organizations. Interested adult cSLE patients were asked to approach the study team. All patients were seen for a single study visit. Patients' current health status was assessed with an extensive medical interview and physical examination. All previous medical correspondence was retrieved, including information regarding cumulative multisystem involvement, auto-antibody profiles, drug use and comorbidities. SLE disease activity index-2K (SLEDAI-2K) and SLICC damage index (SDI) was calculated. Quality of life and related factors such as educational and work status, fecundity, fatigue and depressive symptoms were assessed.

${ }^{1}$ Paediatrics, University Medical Centre Utrecht, Utrecht, Netherlands Full list of author information is available at the end of the article

\section{Results}

31 patients ( $87 \%$ female) are currently included with a median age at diagnosis of 13 years (range 9-18) and median disease duration at time of visit was 15 years (range 4 - 36). At time of visit, median SLEDAI-score was $4(0-9) .20 / 31(65 \%)$ patients had an SDI-score of at least 1 (median 1 , range $0-7$ ). Current medication use included hydroxychloroquine in $63 \%$ of all patients, prednisone in $52 \% .48 \%$ of the patients were treated with at least one DMARD (MMF (27\%), Azathioprine (25\%) and others). Half of the patients ever had CNS involvement. Two thirds of patients ever had renal involvement. Of these patients, 33\% had current proteinuria (>50 $\mathbf{~ m g} / \mathbf{m m o l}$ ). Four (13\%) patients had a renal transplantation. During their disease course, 32\% of the patients had been hospitalised at least once due to a severe infection. Analyses on factors related to quality of life are pending. Table 1.

\section{Conclusion}

cSLE is associated with significant long-term consequences, including frequent renal and CNS involvement, accrual of damage in the majority of patients and almost all patients still using DMARDs, prednisone, hydroxychloroquine or combinations thereof.

\section{Disclosure of interest}

None declared.

\section{Authors' details}

${ }^{1}$ Paediatrics, University Medical Centre Utrecht, Utrecht, Netherlands.

${ }^{2}$ Pediatric Immunology/Infectious diseases/Rheumatology, Erasmus MCSophia, Rotterdam, Netherlands. 
Table 1

\begin{tabular}{|c|c|c|}
\hline Characteristic & \multicolumn{2}{|c|}{$\begin{array}{l}\text { Frequency (median + } \\
\text { range) }\end{array}$} \\
\hline Age at diagnosis & \multicolumn{2}{|c|}{13 years $(9-18)$} \\
\hline Disease duration & \multicolumn{2}{|c|}{15 years $(4-36)$} \\
\hline SLEDAI-score & \multicolumn{2}{|l|}{$4(0-9)$} \\
\hline SDI & \multicolumn{2}{|l|}{$1(0-7)$} \\
\hline \multicolumn{3}{|l|}{ Cumulative organ involvement } \\
\hline Skin & \multicolumn{2}{|l|}{$90 \%$} \\
\hline Muskuloskeletal & \multicolumn{2}{|l|}{$83 \%$} \\
\hline Haematological & \multicolumn{2}{|l|}{$83 \%$} \\
\hline Renal & \multicolumn{2}{|l|}{$65 \%$} \\
\hline Central nervous system & \multicolumn{2}{|l|}{$48 \%$} \\
\hline Pulmonary & \multicolumn{2}{|l|}{$46 \%$} \\
\hline Cardiovascular & \multicolumn{2}{|l|}{$36 \%$} \\
\hline Abdominal & \multicolumn{2}{|l|}{$19 \%$} \\
\hline Peripheral nervous system & \multicolumn{2}{|l|}{$10 \%$} \\
\hline (Vertebral) fractures & \multicolumn{2}{|l|}{$23 \%$} \\
\hline Severe infections (hospitalization necessary) & \multicolumn{2}{|l|}{$32 \%$} \\
\hline Medication use & Current & Ever \\
\hline Prednisone & $52 \%$ & $100 \%$ \\
\hline Azathioprine & $25 \%$ & $64 \%$ \\
\hline Cyclophosphamide & $0 \%$ & $36 \%$ \\
\hline Hydroxychloroquine & $63 \%$ & $85 \%$ \\
\hline Rituximab & $0 \%$ & $11 \%$ \\
\hline MMF & $27 \%$ & $46 \%$ \\
\hline Family history & $1^{\text {st }}$ degree & $\overline{2^{\text {nd }} \text { degree }}$ \\
\hline SLE & $14 \%$ & $0 \%$ \\
\hline other auto-immune diseases & $55 \%$ & $57 \%$ \\
\hline
\end{tabular}

Published: 17 September 2014

doi:10.1186/1546-0096-12-S1-P311

Cite this article as: Groot et al:: Long-term outcomes in childhood-onset systemic lupus erythematosus: preliminary results of the CHILL-NL study. Pediatric Rheumatology 2014 12(Suppl 1):P311.
Submit your next manuscript to BioMed Central and take full advantage of:

- Convenient online submission

- Thorough peer review

- No space constraints or color figure charges

- Immediate publication on acceptance

- Inclusion in PubMed, CAS, Scopus and Google Scholar

- Research which is freely available for redistribution

Submit your manuscript at www.biomedcentral.com/submit
C Biomed Central 